\title{
プライマリ緩和ケアにおける省察的実践 Reflective practice in primary palliative care
}

\section{大石 愛*}

\begin{abstract}
要 旨
プライマリ・ケア従事者にとって，緩和ケアは親和性の高い分野であり，その実践を通して学べる ことは多い，プライマリ緩和ケアにおいて，障壁となりうる状況はいくつかあるが，これらは省察的 実践によって解決される可能性がある. プライマリ・ケア従事者にとっての緩和ケアの困難感を減少 させるためにも，省察的実践を取り入れることが望まれる.
\end{abstract}

Key Words : 省察的実践, プライマリ·ケア, 緩和ケア

\section{はじめに}

患者ニーズの複雑化が進む現代の医療において, 臨 床家は複雑な問題に対応するための何らかの対策を身 につけて㧍く必要がある. ショーンの提唱した省察的 実践に基づく専門家モデルが家庭医と親和性が高いこ とは既に連載第 1 回で述べられた。緩和ケアも省察的 実践に親和性が高い専門分野であり, 緩和ケア専門家 は無意識のうちに省察的実践を行っていることも多 い. 本稿に押いては, 緩和ケア専門家にとっての省察 的実践の意義ではなく, 家庭医を含むプライマリ・ケ ア従事者が緩和ケアに取り組む際に省察的実践の行う ことの意味や方法について考察する。

\section{プライマリ・ケアにとっての緩和ケア}

プライマリ・ケア医にとって緩和ケアは非常に重要 な領域であると聞いて, 真っ向から否定するものは少 ないだろう. 少なくとも, 昨今のプライマリ・ケア, 総合診療への追い風は, 来る未曾有の多死社会におけ るへルス・ケアの担い手として我々が期待されている ことに由来しているのは間違いないだろう。

しかし，プライマリ・ケア従事者にとって緩和ケア が重要であるのは，このような背景だけが理由ではな い. 患者を全人的に理解し QOL の向上を目標とする 緩和ケアの理念が，プライマリ・ケアの目標と合致す
ることは既に多くの研究で指摘されている た，家庭医の定義を「特定の人，家族，地域に対して 継続的に関わっていく仕事」3) とするならば，健康関 連の大きなライフイベントを共に経験し, 臨死期に生 じる困難を患者・家族と共有することの意味は計り知 れない.

緩和ケアが必要な患者には, 複雑で困難な問題が生 じることが多く，教科書的答えのない場面にしばしば 遭遇する。「家庭医は不確害性を受け入れ, 確率を探 り, リスクを軽減する」とは, 英国家庭医療学会のレ ポート に) に用されている一節であるが，これは緩和 ケアにもまさしく当てはまる. 他の医学の専門性が, 基本的には不確害性を減じることを目的としているこ とと一線を画して扔り，この点に抽てプライマリ・ ケアと緩和ケアは大きな共通点を持っていると言え る。プライマリ・ケア医も緩和ケア専門家も,「不確 実性を受容する」専門家として, 日々患者ケアを前進 していくためには省察をせざるを得ないのである（reflection-in-action).

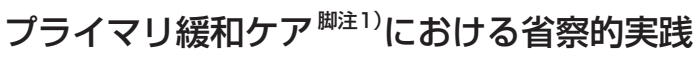 プライマリ緩和ケアにおける省察の意義}

ショーンは,「複雑性」「不確実性」「不安定性」「個 別性」「価值観の対立」の五つの要素を専門家の自信

\footnotetext{
*生協浮間診療所 (非常勤) email：aieye95@gmail.com 脚注 1 :ここではプライマリ・ケア従事者が行う緩和ケアを「プライマリ緩和ケア」と呼ぶこととする. 国際的には, 緩和ケ ア専門医以外が行う緩和ケアの呼称は用語が混乱しているのが実状であり，他に「ジェネラリスト緩和ケア」という用語もし ばしば使われる。
} 
を脅かすものとして挙げている ${ }^{5)}$. 特に緩和ケアの現 場では，これらの五つの側面が露わになりやすい．家 庭医にとっては，それまで極めて安定していた（よう に見えていた）症例が，緩和ケアが必要な状況になっ て困難な状況となるということもあり得る。

前述の通り reflection-in-action は, ケアのなかで 自然に行われていることが多いが，それ以外に改めて 場を設けて省察することも重要である（reflection on action, reflection for action). 省察による経験の蓄積 は, reflection for actionを経ることにより，他の場 面にも応用可能な clinical pearlにまで落とし込むこ とができる6).

このような省察のプライマリ緩和ケアにおけるメ リットは大きく分けて二点ある。一つは，家庭医に とって, 決して多くない緩和ケアの症例から最大限の 学びを得られることである. 現在，プライマリ・ケア 従事者が緩和ケアに必要な知識について学ぶ機会は増 えているが，現場に落とし込むところまで学習が追い 付いていないのが現状である7 . 実際の現場で臨床家 が困難を感じているのは，単純な身体症状のコント ロールにとどまらない複雑な状況，あるいは身体症状 のコントロールを達成するためにクリアしなければな らない複雑な状況にどのように対応すべきかという点 である。この状況を解決するためには reflection が最 も効果的な方法の一つである。

もう一点は, 省察の実践で得られた clinical pearl は緩和ケア以外の領域でも役に立つ可能性が十分ある という点である。 上述の通り，今までの専門的知識だ けでは解決しない状況が緩和ケアの局面では究極的な 形で出現することも多く ${ }^{2)}$ (脚注 2$)$ ，丁寧な省察を 行っておくことが, 緩和ケア領域以外の困難事例の理 解にも必ず役に立つ。

\section{緩和ケアが困難な理由とその対策としての省察}

プライマリ・ケア医が緩和ケアに取り組む際に, 様々な困難感を感じていることも多く指摘されてい る。文献的には「時間不足」が取り上げられることが 多いが，ここでは省察の際に認識しておくと理解が哚 まるであろうという観点から, 非がん疾患と在宅医療 の現場の困難さについて取り上げる.

\section{非がん疾患の緩和ヶア}

近年，非がん疾患の緩和ケアの重要性が認識されつ
つあると同時に，その難しさも整理されてきた。終末 期非がん疾患患者は, Biomedical な側面だけでも, 複雑, 不確実, 不安定であり, 個別性が高く, 価值観 の対立（症状緩和的治療と原疾患治療のせめぎ合い） も生じる。本連載第 2 回「クリニカル・ジャズ（Clinical Jazz)」でも指摘されているように，振り返りの際 には文献検索をすることが望ましい。しかし，現時点 において非がん疾患の緩和ケアのエビデンスは蓄積し ているとは言いがたく，二次資料のレベルで文献が見 つかる可能性は低い.

このような状況を踏まえて, Murtagh らは, 非が ん疾患の緩和ケアにおいて想像力を利かせた臨機応変 な対応が必要となることが多いことを指摘し，「不確 実性のアクティブ・マネジメント」を提唱した ${ }^{8)}$. 若 干古い論文ではあるが，非がん疾患の緩和ケアの全体 像を概説し，不確実性のマネジメントに限局している 点で貴重な論文と言えよう。

\section{在宅医療という現場}

現在の日本に拀いて，プライマリ・ケア医の行う緩 和ケアの多くは在宅医療の場で行われている。しか し，在宅医療のスタンダードは，まだ確立されている とは言い難い。また，在宅医療は本質的に地域特異性 を内包するため，そもそもスタンダードが成立しにく いという特徴を持っている. どこまでの医療的介入が 正しいという基準があいまいになりがちで，そのため ケア従事者の困惑も生じやすい.

日本のような定期訪問診療を行っている国は世界的 には稀であることもあり，非がん疾患の緩和ケア以上 に「在宅医療」という文脈でのエビデンスを得ること は難しいだろう。他の領域と比べてエビデンスが不足 した状況で, 地域の文脈に照らし合わせながら振り返 りを行うことが必要となる。現実的には難しいことも あると思われるが，ここではあえて，多事業所，多職 種での振り返りの重要性を強調したい。地域の文脈を 踏まえる必要がある以上, 一事業所の視点だけでは得 られない全体像がまず間違いなく存在するからである.

\section{デス・カンファレンス（死亡症例検討）}

緩和ケア領域で外観的に最もわかりやすい省察の例 は, デス・カンファレンスと呼ばれることの多い死亡 症例の検討会だろう．形式は施設ごとに異なるが，死 亡症例に関わったスタッフが意見や感想を述べ合うと いう形が一般的であると思われる。デス・カンファレ

脚注 $2 ：$ 連載第 6 回の「困難事例」に相当する形になることも多いはずである. 
ンスの理想的な形について一定の見解があるわけでは ないが, 構造的な振り返り (連載第 2 回, 図 2 参照 ${ }^{6)}$ ) を取り入れることは，一定の効果があると思われる。 もし，デス・カンファレンスの運営に模索しているの であれば，試してみることを敃勧めしたい．

\section{おわりに}

緩和ケア, 特にプライマリ緩和ケアにおける省察的 実践の概要を示した，筆者は，緩和ケアに取り組む際 の家庭医の強みは，その方の人生の終末期というライ フステージに光を当てつつ，近くに寄ったり離れたり しながら人生の全体像を時間的空間的に把握できるこ とであると考えている。このようなプライマリ緩和ケ アを実現するために，省察的実践は有用な手段となり 得る，今，取り組んでいる緩和ケアに不全感を感じて いる読者が，省察的実践を取り入れて患者と向き合う ことで，少しでも前進していることを感じてもらえた ら幸いである。

\section{文 献}

1) Gott, M. ; Seymour, J. ; Ingleton, C. ; Gardiner C,
Bellamy, G. 'That's part of everybody's job' : the perspectives of health care staff in England and New Zealand on the meaning and remit of palliative care. Palliative Medicine. 2012, vol. 26, no. 3, p. 232-241.

2) Field D. Special not different : general practitioners' accounts of their care of dying people. Social Science and Medicine. 1998, vol. 46, no. 9, p. 1111-1120.

3) 藤沼康樹. 省察的実践家 (Reflective Practitioner) とは何か．日本プライマリ・ケア連合学会誌. 2010, vol. 33, no. 2, p. 215-217.

4) Royal College of General Practitioners. Medical generalism. 2012, p. 1-63.

5) Schon DA. The Reflective Practitioner : How Professionals Think In Action. Basic Books, 1984, 384 p.

6）横林賢一.クリニカル・ジャズ (Clinical Jazz). 日 本プライマリ・ケア連合学会誌. 2010, vol. 33, no. 3, p. 322-325.

7）第 4 回 日本プライマリ・ケア連合学会学術大会 ワー クショップ「ジェネラリストに必要な緩和ケアのスキ ルとは?」. (未発表)

8) Murtagh, F. E. M, ; Preston, M. ; Higginson, I. Patterns of dying: palliative care for non-malignant disease. Clinical Medicine. 2004, vol. 4, no. 1, p. 3944.

口「省察的実践家入門」の既掲載一覧

省察的実践家（Reflective Practitioner）とは何か

クリニカルジャズ（Clinical Jazz）

看護教育に打ける省察的実践理論の展開

病院総合医のための SEA（significant event analysis)

一勤医協中央病院に扔けるヒヤリハットカンファレンスの実践一

日本に㧍けるバリントグループの展開

困難事例をチームで振り返る一その方法

卒前医学教育に打ける省察（Reflection）の導入

プロフェッショナリズムと省察的実践

離島診療における省察的実践と状況的学習

指導医としての省察的実践

ナラティブと省察的実践〜看護教育への適用

医療者にとっての自己への気づき（self awareness）の重要性

対話の場作りをすすめるファシリテーターと省察的実践

プライマリ緩和ケアに扔ける省察的実践
藤沼康樹 $33(2) ： 215,2010$

横林賢一 33 (3)：322，2010

永井睦子 $33 （ 4) ： 427 ， 2010$

臺野巧 34 (1)：80, 2011

小嶋一 $34(2): 167,2011$

朝倉健太郎 34（3）: 277，2011

錦織宏 34 (4)：360, 2011

宮田靖志 35 （1）：70， 2012

本村和久 $35 （ 2) ： 165,2012$

中村琢弥 $35(3): 249,2012$

遠藤淑美 35 (4)：360, 2012

今村弥生 36 (1) : 47, 2013

孫大輔 36 (2)：124，2013

大石愛 $36(3): 246,2013$ 